\title{
Sosyo
}

Ekonomi

\section{Kurumsal Yapı ve İktisadi Büyüme İlişkisi: Türkiye Örneği}

\author{
Seyfettin ARTAN \\ artan@ktu.edu.tr
}

Pınar HAYALOĞLU

pinarhayaloglu@gumushane.edu.tr

\section{The Relationship between Institutional Structure and Economic Growth: The Case of Turkey}

\begin{abstract}
In recent years, institutional economic thought, which argues that economic life cannot considered freely from institutions' effects, is an important center of interest. With institutional economic thought, as the view that has stepped forward is that some prominent factors which are referred to as the determiners of growth in traditional growth theories, could be described as the factors identified by institutions' incentives and the institutional structure has been the main point to focus on growth analysis. As a result, the role of institutions and the institutional structure in the process of economic growth has become one of the most emphasized topics of economists' research. In this study, the relationship between institutional structure and economic growth analyzed for Turkey the period of 1972-2009. The results of the study show that political freedom which taken as an indicator of the level of the institutional structure have a positive effect on the long run economic growth but it couldn't be found a relationship between institutional structure and economic growth in the short run.
\end{abstract}

Keywords

: Institutional Structure, Economic Growth, Co-integration Analysis.

JEL Classification Codes $\quad$ : $\quad$ B25, C32, O43.

Özet

Son yıllarda ekonomik yaşamın kurumların etkisinden bağımsız olarak değerlendirilemeyeceğini savunan kurumsal iktisadi düşünce önemli bir ilgi odağı olmaktadır. Kurumsal iktisadi düşünceyle birlikte, geleneksel büyüme teorilerinde büyümenin belirleyicileri olarak ifade edilen unsurların kurumların sağlamış olduğu teşvikler sonucu belirlenen faktörler olduğu ve büyüme analizlerinde odaklanılması gereken asıl noktanın kurumsal yapı olduğu görüşü ön plana çıkmıştır. Bu doğrultuda kurumlar ve kurumsal yapının iktisadi büyüme sürecindeki rolü iktisatçıların üzerinde en çok durduğu araştırma konularından biri haline gelmiştir. Bu çalışmada kurumsal yapı ve iktisadi büyüme ilişkisi, 1972-2009 yıllarını kapsayan dönemde Türkiye için test edilmiştir. Analiz sonuçları, çalışmada kurumsal yapının göstergesi olarak alınan politik özgürlükler düzeyinin iktisadi büyümeyi uzun dönemde olumlu yönde etkilediğini göstermekle birlikte, kısa dönemde kurumsal yap1 ve iktisadi büyüme arasında bir ilişki tespit edilememiştir.

Anahtar Sözcükler $\quad$ : Kurumsal Yapı, İktisadi Büyüme, Eşbütünleşme Analizi. 


\section{Acknowledgement}

This paper is regenerated from the dissertation of P1nar Hayaloğlu which was advised by Assoc.Prof.Dr. Seyfettin Artan in 2012. This study was presented in the "Eurasian Forum on Social Sciences" which was held by Hacettepe University and Azerbaijan State Economic University, on October 18-21, 2012, in Baku, Azerbaijan.

\section{Beyan}

$\mathrm{Bu}$ makale Doç.Dr. Seyfettin Artan’ın akademik danışmanlığında Pınar Hayaloğlu tarafından hazırlanan ve 2012 yılında savunulan doktora tezinden üretilmiştir. $\mathrm{Bu}$ çalışma Hacettepe Üniversitesi ve Azerbaycan Devlet İktisat Üniversitesi tarafindan 18-21 Ekim 2012 tarihleri arasında Azerbaycan'ın Bakü şehrinde gerçekleştirilen Avrasya Sosyal Bilimler Forumu'nda tebliğ olarak sunulmuştur. 


\section{Giriş}

İktisat yazınının temel tartışma konularından biri olan bazı ülkelerin neden diğer ülkelerden daha hızlı büyüdüğü sorusu son zamanlarda kurumsal iktisatçılar tarafından da tartışılmaktadır. Neo-klasik büyüme yaklaşımlarının aksine kurumsal iktisadi düşünceye göre, iyi ve güçlü kurumlar ekonomik performans üzerinde pozitif etkide bulunurken kötü ve zayıf kurumlar ekonomik büyümeyi olumsuz etkilemektedir. Bu kapsamda kurumların ekonomik büyüme üzerindeki etkisi doğrudan ya da dolaylı yollarla gerçekleşebilmektedir. $\mathrm{Bu}$ alanda yapılan birçok çalışmada özellikle zayıf bir kurumsal yapının ekonomik büyüme üzerindeki etkileri analiz edilmektedir. Örneğin Acemoğlu ve diğerleri (2001, 2003), kötü kurumların yatırım ve ekonomik gelişmeye zarar veren unsurlar olduğunu belirterek kurumsal yapının zayıf olduğu ülkelerde daha fazla ekonomik istikrarsızlık yaşandığını ileri sürmüşlerdir. Yazarlara göre, kurumsal açıdan zayıf toplumlarda politikacılar üzerindeki kısıtlamalar fazla olmadığından politik gücü kontrol edenler büyük kazanımlara sahip olurken, politik gücü kontrol edemeyenler kayba uğrarlar. Bunun yanında zayıf kurumsal yapılarda politik gücü elde etmek için guruplar arasında çatışma yaşanacak, bu da politik ve ekonomik karmaşaya neden olacaktır. Ayrıca zayıf kurumlar nedeniyle sözleşmeye bağlı düzenlemeler daha kusurlu olacak ve ekonomik ilişkileri şoklara karşı daha duyarlı hale getirecektir.

Kurumların ülkelerin ekonomik büyümelerinin belirleyicilerinden biri olduğu konusundaki tartışmalar A. Smith (1776)'e kadar uzanmakla birlikte bu alandaki çalışmaların özellikle 1990'l1 yıllardan sonra artış gösterdiğini söylemek mümkündür. Smith'in kişisel çıkarların ön planda olduğu bir ortamda görünmez elin toplum çıkarlarını maksimize edeceği ve dolayısıyla hükümetlerin piyasalara müdahale etmemesi gerektiğ $i$ yönündeki iktisadi liberalizmi savunan felsefesi, kurumların büyüme surecindeki rolüne ortaya koyduğu şeklinde yorumlanmaktadır. Diğer yandan kurumların önemini vurgulayan ilk araştırmacılardan biri olan Friedrich List (1856), 1841'de yayınlanan ve 1856'da İngilizceye çevrilen kitabında, ulusların üretici gücünün yalnızca çalı̧̧maya, tasarrufa, ahlaka ve bireylerin akıllı, yaratıcı, girişimci olmalarına bağlı olmadığını; bunun mutlaka sosyal, politik ve sivil haklar gibi kurumsal unsurlarla desteklenmesi gerektiğini ileri sürmektedir. Çünkü List (1856)'e göre; bireysel çabalar kalıcı bir refah artış1 sağlamayacaktır. Bununla birlikte North (1991), Barro (1994), De Haan ve Siermann (1995), Mauro (1995), Rodrik (2000), Acemoğlu ve diğerleri (2001), Scully (2002), Acemoğlu ve diğerleri (2003) ve Dawson (2003)'un çalışmaları bu alandaki daha yeni çalışmalardır. Özellikle günümüzün önemli kurumsal iktisatçılarından Douglas North ve Daron Acemoğlu'un çalışmaları kurumsal iktisada önemli katkılar olarak nitelendirilmektedir.

Kurumların iktisadi büyüme sürecindeki önemini araştıran deneysel araştırmalar incelendiğinde, çalışmalarda genelde çok sayıda ülkenin panel veri ya da yatay-kesit analiz yöntemleri ile araştırıldığını, zaman serisi kullanan tek ülkeli çalışmalara ise az sayıda da olsa rastlanıldığı göze çarpmaktadır. Ayrıca bu çalışmaların bir kısmında iktisadi faktörlerin kurumsal yapı tarafından belirlendiği görüşünden yola çıkarak büyümenin açıklanmasında 
sadece kurumsal yapıyı dikkate almakta olduğu, diğer bir kısım çalışmaların ise kurumsal yap1 yanında iktisadi faktörleri de göz önünde bulundurduğu tespit edilmiştir. Son olarak, yapılan analizlerden elde edilen sonuçlar kullanılan yönteme, ülke grubuna ve zamana bağlı olarak değişmektedir.

Özellikle son yıllarda gerek Avrupa Birliği (AB) uyum çalışmaları çerçevesinde gerekse yeni anayasa hazırlıkları sürecinde yapılan yasal düzenlemelerin Türkiye'de kurumsal yapının güçlendirilmesine katkı sağlayacağı düşünülmektedir. Bu doğrultuda çalışmada; kurumsal düzenlemeler sonucunda ortaya çıkacak daha güçlü bir kurumsal yapının Türkiye ekonomisi üzerindeki muhtemel etkilerinin neler olabileceğine ilişkin tartışmaya bir zemin oluşturmak amaçlanmıştır. Bu amaçla, kurumsal yapının iktisadi büyüme sürecindeki rolü zaman serisi verilerinden yararlanılarak Türkiye örneği için test edilmiştir. Analizde kurumsal değişkenlerin yanı sıra iktisadi değişkenler de kullanılmıştır.

Beş bölüm olarak hazırlanan çalışmanın ikinci bölümünde kurumsal iktisadın büyüme konusundaki görüşlerine değinilmiş, üçüncü bölümde kurumsal yap1 ve büyüme ilişkisini ele alan deneysel literatüre yer verilmiştir. Dördüncü bölümde Türkiye'de kurumsal yapı ve iktisadi büyüme ilişkisini test etmek için kullanılan ekonometrik yöntem ve veri seti tanıtılmıştır. Çalışmanın beşinci bölümü olan deneysel bulgular kısmını, sonuç ve değerlendirme kısmı takip etmiştir.

\section{Kurumsal İktisat ve Büyüme}

Kurumsal İktisat, öncülüğünü Thorstein B. Veblen, John R. Commons ve Wesley C. Mitchell'in yaptı̆̆g, Amerikalı iktisatçılar tarafından ortaya atılmış bir iktisadi düşünce akımıdır. Kuruluşu 19. yüzyılın sonlarına dayanmakla birlikte okulun esas yükselişi Birinci Dünya Savaşı'ndan sonraki yıllarda yaşanmıştır. Amerikan kökenli bir düşünce akımı olan kurumsal iktisadın fikri temelleri Alman Tarihçi Okulu, pragmatik felsefe ve Darwin'in evrim teorisine dayanmaktadır.

Neo-klasiklere tepki olarak ortaya çıkan kurumsal iktisat okulunun diğer iktisat okullarından ayrılan en önemli noktası, iktisadi performansı şekillendirmede kurumlara merkezi bir rol vermesidir. Bu yönüyle kurumsal iktisadın ana inceleme konusu kurumlardır. Ancak kurumsal iktisat literatüründe çok sayıda kurum tanımı söz konusudur. Örneğin Veblen (1919: 314), kurum kavramını; "bireylerin ve toplumun genelinde var olan yaygin düşünce alışkanlıkları" olarak tanımlarken; Hamilton (1932: 84), "bir grubun sosyal alışkanlıkları ya da bir toplumun geleneklerine yerleşmiş, sürekliliği olan düşünce veya eylem tarzı" olarak ifade etmiştir. Mitchell (1950: 373), benzer şekilde kurumu "yaygın şekilde kabul gören, yüksek düzeyde standartlaşmış sosyal alışkanlıklar" olarak tanımlamıştır. Kurumsal iktisadın öncülerinden bir diğeri olan Commons (1931: 648-649), kurumu "bireysel eylemin kontrolünde, serbestleştirilmesinde ve genişletilmesinde ortaya 
çıkan toplu eylem" olarak tanımlamıştır. Yeni kurumsal iktisadın ${ }^{1}$ önemli bir ismi olan North'a (1991: 1) göre ise kurumlar, "insanlar tarafindan oluşturulmuş politik, ekonomik ve sosyal etkileşimi planlayan kisıtlamalar"dır. Kısaca kurumsal iktisadi düşünceye göre kurumlar; insanlar tarafindan oluşturulmuş, insanlar arasındaki etkileşimleri belirleyen düşünce alışkanlıkları şeklinde tanımlanmaktadır.

Kurumsal yaklaşım, ekonomik, yasal ve politik kurumlara odaklanarak uygun kurumların bulunması durumunda piyasa sisteminin, piyasa katılımcılarını beşeri ve fiziksel sermayeye yatırım yapmaları için teşvik sağladığı ve yeniliğe yönelik üretim metotlarını geliştireceklerini öne sürmektedir (Gwartney ve diğerleri, 2004: 207). Kurumların en önemli işlevi; sistematik, gelişigüzel olmayan ve bu nedenle anlaşılabilir eylem ve olaylar modeli oluşturmayı kolaylaştırmaktır (Kasper ve Streit, 1998: 28-29).

Kurumcu düşünceye göre kurumların toplumda oynadığı rol oldukça önemlidir. Etkin kurumların toplumlar açısından birtakım avantajlar sağlamaktadır. Bu avantajlar şu şekilde sıralanabilir (Kasper, 2007: 68-70):

Öncelikle, saygı duyulan kurumlar bilgi arama sürecini kolaylaştırır, böylece insanlar birbirleriyle güven içinde ve kolayca etkileşimde bulunabilirler. Yani iyi kurumlar iş yapmayı hızlandırır ve sosyal etkileşimi kolaylaştırır. İkinci olarak etkin kurumlar, bireyin özgürlük alanını muhafaza eder. Uygun kurallar güç kullanımını sınırlar. İyi kurumlar aşırı ve gereksiz baskıyı önler ve başkalarının özgürlügünü zedelemeden insanların kendi çıkarları peşinde koşmasına olanak sağlar. Uygun kurumsal kısıtlamalar olmaksızın özgürlük izinli hale gelecek ve serbestlik ortadan kalkacaktır. Üçüncü olarak, etkin kurumlar aynı zamanda çatışmaların ortadan kalkmasını sağlayarak toplumsal barışa da hizmet eder. Farklı isteklere, farklı hedeflere ulaşmak için kaynaklarını yönlendiren farklı insanlar arasında kaçınılmaz olarak çatışmalar ortaya çıkacaktır. Dolayısıyla, örneğin trafik kurallarının amacı gecikmeler ve kazaları engellemektir. Son olarak, uygun kurumlar kıt kaynakların korunmasını teşvik eder. Kurumlar belli malların sahiplerine bunların sahipliğini sürdürebilme hakkı verdiğinde (örneğin mülkiyet haklarını güvence altına alan kurumlar gibi) insanlar mallarını kendi geleceklerinin daha refah içinde olması için yönlendireceklerdir. Kurumsal koruma güvensiz olduğunda varlıklarını kontrol eden insanlar bunların küçülmesini önemsemeyecektir.

Kısaca kurumlar bireylerin etkileşiminde istikrarlı yapılar oluşturarak belirsizliği azaltmaktadırlar. Bununla birlikte kurumcu düşünceye göre etkin kurum ve kurumsal yap1 bir taraftan bireyler arası etkileşime yön verirken diğer yandan ekonomik performansı da

1 Kurumsal iktisadi düşünce, Eski ve Yeni Kurumsal İktisat olmak üzere iki temel görüş etrafinda ele alınmaktadır. Aralarındaki en temel fark yeni kurumsal iktisadın metodolojik açıdan Neoklasik iktisada benzemesidir. Eski kurumsal iktisat, Neo-klasik iktisadın varsayımlarını tümüyle eleştirmekte ve bu yaklaşımın tamamen terk edilmesini önermektedir. Yeni kurumsal iktisatçllar ise, Neo-klasik iktisadın yeniden düzenlenmesini savunmaktadırlar. 
etkilemektedir. Etkin kurumsal yapı, işlemlerin daha güvenli gerçekleştirilmesine yol açmakta, bir ekonomideki üretim, yatırım, tüketim gibi kararları etkileyerek ekonomik gelişmeye katkı sağlamaktadır. Bu bağlamda etkin kurumlar bireylere ve girişimcilere beşeri ve fiziksel sermaye yatırımı yapmaları için gerekli olan teşvik unsurunu sağlamaktadır. Çünkü kuralların hâkim olduğu bir ekonomide geleceği öngörmek mümkün olacak; dolayısıyla riskli, yenilikçi deneyimlerde insanlar kendilerini güvende hissedeceklerdir. Örneğin mülkiyet haklarının güvence altına alındığı toplumlarda insanlar kendi mülkiyetlerinde bulunan alanlarda kaynaklarını yönlendirmekte daha istekli davranacaklardır.

\section{Literatür Taraması}

İktisadi büyümenin açıklanmasında kurumsal yapı farklılıklarına vurgu yapılması 20. yüzyılın başlarına dayanmakla birlikte kurumsal yapının ekonomik performans üzerindeki etkisinin deneye dayalı olarak incelendiği çalışmalar özellikle 1990'lı yıllarda başlamıştır. Bunun en önemli nedeni, kurumsal yapının tanımlanması ve ölçülmesindeki zorluklar olarak belirtilebilir. Literatüre bakıldığında bu ilişkiyi test eden pek çok araştırmacının kurumsal yapıyı tanımlamak için farklı göstergeler kullandıkları göze çarpmaktadır. Bu doğrultuda teorik ve deneysel çalışmalarda kurumsal yapının ölçüsü olarak yaygın şekilde kullanılan göstergeler; hak ve özgürlükler, hukukun üstünlüğg̈, yolsuzluk düzeyi, mülkiyet hakları, sosyal sermaye ve bürokrasinin kalitesi gibi faktörlerdir.

Bunun yanında, literatürde kurumsal yapı ve iktisadi büyüme ilişkisini test eden çalışmaların büyük çoğunluğunun panel veri analiz yöntemini kullandığg görülmektedir. Kurumsal yapının iktisadi büyüme üzerindeki etkilerini analiz eden tek ülkeli zaman serisi verileri kullanan çalışmalara ise az sayıda olsa da son yıllarda rastlamak mümkündür. $\mathrm{Bu}$ doğrultuda çalışmanın literatür kısmı zaman serisi uygulayan çalışmalar ve panel veri yöntemini kullanan çalışmalar olmak üzere iki bölümde sunulmuştur.

Kurumsal yapı ve iktisadi büyüme ilişkisini birden çok ülke için panel veri analiz yöntemini kullanarak test eden ilk çalışmalardan Barro (1994), kurumsal yapının bir unsuru olarak demokrasinin büyüme üzerindeki etkisini 1960-1990 yıllarını kapsayan dönemde 100 ülke için araştırmış ve demokrasinin büyüme üzerindeki olumlu etkisinin; hukukun üstünlüğü, serbest pazar, kamu harcamalarının küçüklüğü ve yüksek beşeri sermayeye bağlı olduğunu ortaya koymuştur. Söz konusu değişkenler ve kişi başı reel Gayri Safi Yurtiçi Hasıla (GSYH) sabit tutulduğunda, demokrasinin büyüme üzerindeki genel etkisinin negatif olduğu sonucuna ulaşmıştır. De Haan ve Siermann (1995), demokratik rejimin iktisadi büyüme üzerinde doğrudan ve dolaylı etkilerini araştırmış ve demokrasi ile iktisadi büyüme arasında güçlü bir ilişkinin olmadığını ortaya koymuşlardır. Rodrik (2000), 67 ülkeyi kapsayan çalışmasında katılımcı demokrasilerde yüksek kaliteli bir büyümenin sağlandığ 1 yönünde bulgulara ulaşmıştır. Buna göre katılımcı demokrasiler; daha fazla öngörülebilir ve istikrarlı, şoklara karşı dayanıklı ve gelir dağılımında eşitliği sağlayan yüksek kaliteli büyümeye yol açarlar. Tavares ve Wacziarg (2001)'in bulgularına göre ise demokrasi beşeri 
sermaye birikimini arttırarak ve gelir eşitsizliğini azaltarak büyümeyi pozitif yönde etkilemekte, diğer yandan fiziksel sermaye yatırımlarını engelleyerek ve kamu tüketim harcamalarının GSYH'ya oranını yükselterek büyümeyi engellemektedir. Bu iki etki göz önünde bulundurulduğunda, demokrasinin ekonomik büyüme üzerindeki genel etkisi negatif ve zayıftır.

Carlsson ve Lundström (2001), ekonomik özgürlüğün büyüme üzerindeki etkisini 1975-1995 yıllarını kapsayan dönemde 74 ülke için analiz ettikleri çalışmalarında ekonomik özgürlügün bazı bileşenlerinin büyümeyi pozitif bazı bileşenlerinin ise negatif etkilediğini ortaya koymuşladır. Scully (2002)'nin çalışmasından elde edilen bulgular ise ekonomik özgürlük düzeyinin ekonomik büyümeyi pozitif yönde etkilediği yönündedir. Dawson (2010), ekonomik özgürlük ile makroekonomik oynaklık arasındaki ilişkiyi incelemiş ve söz konusu ilişkinin negatif yönlü olduğu bulgusuna ulaşmıştır. Diğer yandan Vanssay ve Spindler (1994), 100 ülke için yaptıkları çalışmalarında ekonomik özgürlükler ile iktisadi büyüme arasında güçlü bir ilişkinin olmadığını yönünde bulgulara ulaşmışlardır. Dawson (2003)'un çalışmasında elde ettiği bulgular ise, ekonomik ve politik özgürlüklerin iktisadi büyümedeki artışın en önemli nedeni oluğunu göstermektedir.

Siddiqui ve Ahmed (2010)'in çalışmalarında, kurumsal kalite ile ekonomik performans arasındaki ilişki araştırılmıştır. 43 ülke için yapılan çalışmada kurumsal kalite ve ekonomik büyüme arasında güçlü bir bağlantı olduğu yönünde sonuçlara ulaşılmıştır. Torstensson (1994), mülkiyet haklarının ekonomik büyüme üzerindeki etkisini 1976-1985 döneminde 68 ülke için analiz etmiştir. Çalışmada mülkiyet haklarının, "devletin mülkiyet derecesi" ve "keyfi el koymanın varlığı (arbitrary seizure of property)" olmak üzere iki yönü dikkate alınmıştır. $\mathrm{Bu}$ araştırmanın sonuçlarına göre, devlet mülkiyeti ile büyüme arasında negatif ve anlamlı olmayan bir ilişki söz konusudur. Bununla birlikte keyfi el koyma ile ekonomik büyüme arasında negatif ve anlamlı bir ilişki olduğu gözlemlenmiştir.

Akçay (2002), yolsuzluğun ekonomik büyüme üzerindeki etkisini 54 ülke için incelemiştir. Araştırmanın temel bulgusu, yolsuzluk ile ekonomik büyüme arasında istatistiksel olarak negatif ve anlamlı bir ilişki olduğudur. Mauro (1995), yolsuzluğun düşük yatırım oranına yol açarak ekonomik büyüme üzerinde olumsuz etkide bulunduğunu tespit etmiştir. Tanzi ve Davodi (1997), OECD ülkeleri için yaptı̆̆ 1 çalışmasında yüksek yolsuzluğun iktisadi büyümeyi etkilediği kanalları ortaya koymuştur. Buna göre yüksek yolsuzluk yüksek kamu yatırımlarına, düşük kamu gelirlerine, düşük işletim ve bakım harcamalarına ve düşük kamu alt yapı kalitesine yol açmak suretiyle iktisadi büyümeyi etkilemektedir.

Kurumsal yapının iktisadi büyüme üzerindeki etkilerini inceleyen tek ülkeli çalışmalardan biri olan Asteriou ve Price (2000), kurumsal yapının bir unsuru olarak siyasi istikrarsızlığın ekonomik büyüme üzerindeki etkisini İngiltere için test etmişlerdir. 1961 ve 1997 dönemini kapsayan araştırmada siyasi istikrarsızlığı ölçmek ve büyüme üzerindeki etkisini incelemek için altı farklı değişken (terör, darbe, seçim, rejim ve iki savaş dönemi 
için kukla değişkenler) kullanılmıştır. Elde edilen sonuçlar siyasi istikrarsızlık ve ekonomik büyüme arasında güçlü bir ilişkinin varlığını ortaya koymaktadır. Bununla birlikte siyasi istikrarsızlık büyüme üzerinde olumsuz etkiye sahipken, ekonomik belirsizlik üzerinde pozitif bir etkiye sahiptir. İstikrarsız bir siyasi sistem ve çevreden kaynaklanan belirsizlik özel yatırımların düşmesine neden olabilmektedir. $\mathrm{Bu}$ da ekonomik büyümeyi olumsuz etkilemektedir. Diğer yandan belirsizlik, gerçekleştirilen yatırımların türünü, diğer faktör taleplerini veya kamu harcamalarının bileşimini değiştirebilmekte ve böylece ekonomik büyüme üzerinde doğrudan etkili olabilmektedir.

Sabatini (2006), sosyal sermaye ve ekonomik kalkınmanın kalitesi arasındaki ilişkiyi İtalya için araştırmıştır. Çalışmada ekonomik kalkınmanın farklı yönlerini temsil eden yaklaşık 200 değişken yanında sosyal sermayenin yapısal boyutuna ilişkin dört göstergeden oluşan geniş bir değişken seti kullanılmıştır. Kalkınmanın kalitesini ölçmek için insani gelişmişlik ve kentsel ekosistemlerin sağlık durumu, kamu hizmetleri, toplumsal cinsiyet eşitliği ve işgücü piyasaları göstergeleri kullanılmıştır. Sosyal sermaye ise güçlü aile bağları (genellikle bağlayıcı sosyal sermaye), zayıf gayri resmi bağlar (köprü kuran sosyal sermaye), gönüllü organizasyonlar (birleştirici sosyal sermaye) ve siyasi katılımdan oluşan göstergeler ile ölçülmüştür. Çalışmada İtalya'nın bölgelerinde kalkınmanın kalitesi ile zayıf gayri resmi bağlar arasında pozitif, kalkınmanın kalitesi ile güçlü aile bağları arasında ise negatif bir ilişki tespit edilmiştir. Analiz özellikle gayri resmi bağlar ve sosyal refah arasında ve de gönüllü organizasyonlar ve kentsel ekosistemlerin sağlık durumu arasında güçlü bir korelasyon olduğunu göstermektedir. Diğer yandan aktif siyasi katılım ve sosyal refah arasında bir ilişki tespit edilememiştir. Çalışmada son olarak, kamu harcamalarının eğitim, sağlık, sosyal yardım ve çevre korumadaki rolü analiz edilmiş, hem sosyal sermaye ve hem de kalkınma göstergeleri ile aralarında bir ilişki bulunamamıştır.

Şanlısoy ve Kök (2010), politik istikrarsızlı̆̆ın ekonomik büyüme üzerindeki etkilerini Türkiye açısından incelemişlerdir. Çalışmada 1987-2006 yıllarını kapsayan veriler üçer aylık gözlemlerden oluşmaktadır. Politik istikrarsızlığın göstergesi olarak Politik Risk Servisi (PRS: Political Risk Services) tarafından hazırlanan Uluslararası Ülke Riski Rehberi (ICRG: International Country Risk Guide) endeksinden elde edilen politik risk endeksi verileri kullanılmıştır. Söz konusu endeks; siyasi istikrar, sosyo-ekonomik koşullar, yatırım profili, içsel çatışmalar, dışsal çatışmalar, yolsuzluk, politik alanda askerin etkisi, politik alanda dinin etkisi, yasal düzenlemeler, etnik gerilimler, demokratik şeffaflık ve bürokrasi kalitesi olmak üzere 12 alt bileşenden oluşmaktadır. Araştırmanın sonuçları politik istikrasızlıkla ekonomik büyüme arasındaki ters yönlü ilişkinin, literatürle uyumlu olarak Türkiye açısından da geçerli olduğu yönündedir.

Siyasi istikrarsızlık ve ekonomik büyüme arasındaki ilişkiyi Türkiye ekonomisi açısından test eden bir diğer çalışma Arslan (2011)'a aittir. Çalışmada 1987-2007 yılları arası üç aylık veriler kullanılarak siyasi istikrarsızlık ve ekonomik büyüme arasındaki ilişki incelenmiştir. Siyasal istikrarsızlık göstergesi olarak ICRG'den elde edilen veri kullanılırken, ekonomik büyüme GSYH ile ölçülmüsşür. Analiz sonuçları siyasi 
istikrarsızlık ve reel GSYH arasında uzun dönem denge ilişkisinin varlığını işaret etmektedir. Bu bilgiden hareketle nedenselliğin yönünü saptanması amaciyla oluşturulan hata düzeltme modeli sonucuna göre, GSYH'dan siyasi istikrarsızlığa doğru bir nedensellik söz konusuyken siyasi istikrarsızlıktan GSYH'ya doğru bir nedensellik ilişkisine rastlanılamamıştır.

Kurumsal yapı ve iktisadi büyüme ilişkisinin Türkiye için araştırıldığı bir diğer zaman serisi çalışması Beşkaya ve Manan (2009)'a aittir. Beşkaya ve Manan (2009), demokrasi ve ekonomik özgürlükler ile ekonomik performans arasındaki ilişkiyi Türkiye için araştırmışlardır. Çalışmada demokrasi ölçüsü olarak Freedom House'dan elde edilen politik haklar ve sivil özgürlükler endeksi kullanılmıştır. Ekonomik özgürlüğü ölçmek için Fraser Institute tarafindan hazırlanan 'Dünyada Ekonomik Özgürlükler (EFW: Economic Freedom of the World) ${ }^{2}$ endeksi kullanılmıştır. Yapılan testler sonucu, demokrasi ve ekonomik performans arasındaki ilişkinin kurulan kimi modellerde pozitif, kimi modellerde ise negatif olması nedeniyle belirsiz olduğu gözlenmiştir. Diğer yandan, ekonomik özgürlüklerle ekonomik performans arasında pozitif bir ilişki bulunmuştur.

Kurumsal yapı ve iktisadi büyüme ilişkisini ele alan çalışmalar kapsadığı dönem, ülke sayısı, kullandıkları kurumsal gösterge, ekonometrik yöntem ve sonuçları itibariyle Ek 1 'de sunulmuştur.

\section{Ekonometrik Yöntem ve Veri Seti}

Bu çalışmada kurumsal yapı ve iktisadi büyüme ilişkisi 1972-2009 yıllarını kapsayan dönemde yıllık veriler kullanılarak Türkiye için incelenmiştir. Bu amaçla ilk olarak çalışmada kullanılacak değiş̧kenlerin durağan olup olmadıkları araştırılmış, daha sonra Johansen ve Juselius eşbütünleşme yöntemiyle seriler arasında uzun dönemli bir ilişkinin olup olmadığı test edilmiş ve elde edilen sonuçlara bağlı olarak hata düzeltme modeli kurularak kısa ve uzun dönemli ilişkinin varlı̆̆ 5.1 ekonometrik analiz paket programı kullanılmıştır.

Çalışmada kullanılan model; Leschke (2000), Dawson (2003), Ulubaşoğlu ve Doucouliagos (2004) ve Rodrik (2000)'in çalışmalarında kullandıkları modeller geliştirilerek oluşturulmuştur. Buna göre kurumsal yapı ve iktisadi büyüme ilişkisini analiz etmek üzere oluşturulan model aşağıdaki şekildedir:

2 EFW endeksi ekonomik özgürlüklere ilişkin beş temel alana göre oluşturulmaktadır. Bu beş temel alan; 1) Kamu Kesiminin Büyüklüğ̈: Kamu Harcamaları, Vergiler ve Kamu Girişimleri, 2) Hukuki Yapı ve Mülkiyet Haklarının Güvence Altına Alınması, 3) Güçlü Paraya Erişim, 4) Uluslararası Ticaret Özgürlüğ̈̈, 5) Kredi, Işgücü Piyasası ve İşletmelere Yönelik Regülasyonlar olarak sınıflandırllmıştır. Bunun dışında her bir alanın altında farklı 23 bileşen ve bu bileşenlere bağlı alt bileşenler bulunmaktadır. Kısaca EFW endeksi toplam 42 farklı değişkeni kapsamaktadır (Gwartney ve diğerleri, 2010: 4-5). 
$\mathrm{LY}_{\mathrm{t}}=\beta_{0}+\beta_{1} \mathrm{PF}_{\mathrm{t}}+\beta_{2} \mathrm{YAT}_{\mathrm{t}}+\beta_{3} \mathrm{GFCE}_{\mathrm{t}}+\beta_{4} \mathrm{TIC}_{\mathrm{t}}+\beta_{5} \mathrm{INF}_{\mathrm{t}}+\mathrm{u}_{\mathrm{t}}$

(1) nolu eşitlikte; t zamanı, L ilgili değişkenin doğal logaritmasının alındığını ve $\mathrm{u}$ hata terimini ifade etmektedir. Modelde yer alan değişkenlerin tanımlamaları ve elde edildikleri kaynaklar Tablo: 1'de yer almaktadır.

Modelde bağımlı değişken olarak alınan ve Y ile gösterilen reel GSYH değişkeni Dünya Bankası'ndan elde edilmiştir. Kurumsal yapının göstergesi olarak ele alınan politik özgürlükler endeksi ise Freedom House'un politik haklar ve sivil özgürlükler endekslerinin ortalaması alınarak oluşturulmuştur ${ }^{3}$. Ülkelerin politik hak ve sivil özgürlük düzeylerini ölçmek üzere Freedom House kuruluşu tarafından düzenlenen anketlerde ülkelerin politik haklar ve sivil özgürlükler endekslerini belirlemek amacıyla ifade ve inanç özgürlüğü, siyasi sürece eşit katılım ve seçim sürecinde özgürlükler gibi unsurlarla ilgili sorular sorulmaktadır (Hanke ve Walters, 1997: 119). Ülkelerin bu sorulara verilen cevaplara göre aldıkları puanlar 1 en yüksek ve 7 en düşük özgürlük düzeyini göstermek üzere 1 ile 7 arasında olacak şekilde sınıflandırılmakta ve bu puana göre ülkelerin özgürlük derecesi belirlenmektedir. $\mathrm{Bu}$ doğrultuda politik haklar ve sivil özgürlükler puanlarının yıllık ortalaması 1 ile 2.5 arasında olan ülkeler "özgür", 3 ile 5.5 arası ülkeler "kısmen özgür", 5.5 ile 7 arası olan ülkeler "özgür olmayan” ülkeler olarak değerlendirilmektedir (Puddington, 2011: 30).

\section{Tablo: 1}

\section{Modelde Kullanılan Değişkenler}

\begin{tabular}{|c|c|c|}
\hline Değișkenin Adı & Değişkenin Tanımlanması & Elde Edildiği Kaynak \\
\hline $\mathbf{Y}$ & Reel GSYH & Dünya Bankası, WDI \\
\hline PF & Politik Özgürlükler & Freedom House \\
\hline YAT & $\begin{array}{l}\text { Gayri Safi Sabit Sermaye Oluşumları } \\
\text { (GSYH yüzdesi olarak) }\end{array}$ & Dünya Bankası, WDI \\
\hline GFCE & $\begin{array}{l}\text { Kamu Tüketim Harcamaları } \\
\text { (GSYH yüzdesi olarak) }\end{array}$ & Dünya Bankası, WDI \\
\hline TIC & $\begin{array}{l}\text { Ticaret (İhracat ve İthalat Toplamı) } \\
\text { (GSYH yüzdesi olarak) }\end{array}$ & Dünya Bankası, WDI \\
\hline INF & $\begin{array}{l}\text { Enflasyon Oranı } \\
\text { GSYH Deflatörü (yıllık \% değişme) }\end{array}$ & Dünya Bankası, WDI \\
\hline
\end{tabular}

Modele kontrol değişkenleri olarak ilave edilen gayri safi sabit sermaye oluşumlarının GSYH içindeki payı, GSYH içindeki yatırımların yıllar itibariyle yüzde olarak payını; kamu tüketim harcamalarının GSYH içindeki payı, GSYH içindeki kamu sektörü tüketim harcamalarının yıllar itibariyle yüzde olarak payını; ticaretin GSYH içindeki payı, GSYH içindeki mal ve hizmet ithalat ve ihracatının yıllar itibariyle yüzde olarak payını

3 Politik hak ve sivil özgürlükler endekslerinin (politik özgürlükler endeksi) 1982 yılına ait verileri mevcut olmadığından, çalışmada bu yıla ait politik özgürlükler endeksi verisi 1980-1981 ile 1983-1984 verilerinin ortalaması alınarak hesaplanmıştır. 
ve enflasyon oranı, GSYH deflatörü cinsinden hesaplanan yıllık enflasyon oranını ifade etmektedir. Söz konusu değişkenler Dünya Bankası'ndan elde edilmiştir.

\section{Ampirik Bulgular}

\subsection{Birim Kök Testi}

Zaman serisi analizlerinde değişkenler arasında sahte regresyon sorununun ortaya çıkmaması için kullanılan serilerin durağan olması gerekmektedir. Bu nedenle çalışmada öncelikle regresyon denkleminde kullanılan değişkenlerin durağan olup olmadıklarının belirlenmesi için birim kök testi yapılmıştır. Bu doğrultuda, değişkenlerin durağanlıkları genişletilmiş Dickey-Fuller (ADF: Augmented Dickey-Fuller) birim kök testleri kullanılarak araştırılmıştır. Durağanlıkların belirlenmesinde hem sabitli ve trendli hem de sabitli ve trendsiz modeller kullanılmış olup, birim kök testine tabi tutulan değişkenlere ait gecikme uzunluğu Schwarz Bilgi Kriteri (SIC: Schwarz Information Criterion) kullanılarak hesaplanmıştır. Birim kök testi sonuçları Tablo: 2'de sunulmuştur.

Tablo: 2'de görüldüğü üzere, yapılan durağanlık analizleri sonucunda hem sabitli ve trendli hem de sabitli ve trendsiz modellere göre, serilerin tümünün birinci farkında durağan olduğu sonucuna varılmıştır. Serilerin tümünün birinci farkında durağan çıkmaları aralarında uzun dönemli ilişkiyi ortaya koymak üzere eşbütünleşme analizi yapılabileceğini göstermektedir.

Tablo: 2

Birim Kök Testi Sonuçları

\begin{tabular}{|lcccc|}
\hline Değişkenler & SIC & $\begin{array}{c}\text { ADF Test İstatistiği } \\
\text { (sabitli ve trendli model) }\end{array}$ & SIC & $\begin{array}{c}\text { ADF Test İstatistiği } \\
\text { (sabitli ve trendsiz model) }\end{array}$ \\
\hline LY & 0 & -2.731 & 0 & -0.848 \\
PF & 1 & -2.094 & 1 & -2.214 \\
YAT & 0 & -1.609 & 0 & -1.859 \\
GFCE & 0 & -1.572 & 0 & -1.015 \\
TíC & 0 & -2.541 & 0 & -1.247 \\
INF & 0 & -2.341 & 0 & -2.378 \\
$\Delta \mathbf{L Y}$ & 0 & $-5.333^{\mathrm{a}}$ & 0 & $-5.381^{\mathrm{a}}$ \\
$\Delta \mathbf{P F}$ & 0 & $-5.733^{\mathrm{a}}$ & 0 & $-5.765^{\mathrm{a}}$ \\
$\Delta \mathbf{Y A T}$ & 0 & $-4.909^{\mathrm{a}}$ & 0 & $-4.884^{\mathrm{a}}$ \\
$\Delta \mathbf{G F C E}$ & 0 & $-5.352^{\mathrm{a}}$ & 0 & $-5.261^{\mathrm{a}}$ \\
$\Delta$ TíC & 0 & $-5.239^{\mathrm{a}}$ & 0 & $-5.306^{\mathrm{a}}$ \\
$\Delta \mathbf{I N F}$ & 0 & $-6.803^{\mathrm{a}}$ & 0 & $-6.736^{\mathrm{a}}$ \\
\hline
\end{tabular}

Not: a, ilgili değişkenlerin \% 1 düzeyinde anlaml olduğunu; $\Delta$ sembolü ise ilgili değişkenlerin birinci derece farkının alındığını göstermektedir. 


\subsection{Eşbütünleşme Analizi}

Seriler arasındaki çok değişkenli eşbütünleşme ilişkisini belirlemesinde yaygın olarak kullanılan analizlerden birisi Johansen ve Juselius (1990) tarafından geliştirilen ve kendi isimleri ile anılan yöntemdir. Bu yönteme göre; hesaplanan maksimum özdeğer istatistiği ve iz istatistiği değerleri ile Juselius (1990) tarafından verilen tablo kritik değerleri karşılaştırılır. Testler, istatistiksel olarak eşbütünleşik vektör ya da vektörlerin önemli olduğunu gösteriyorsa seriler arasında eşbütünleşme olduğuna karar verilir. Bu durumda seriler arasında uzun dönemli bir ilişki olduğu kabul edilir.

Çalışmada seriler arasındaki eşbütünleşme ilişkisinin belirlenmesinde Johansen ve Juselius eşbütünleşme yöntemi kullanılmıştır. Bu yöntemde ilk adım olarak kullanılan değişkenler için bir VAR modeli oluşturularak modele ilişkin uygun gecikme uzunluğu belirlenmiştir. Bu doğrultuda Tablo: 3'de yer alan VAR modeli sonuçlarına göre, LR (Likelihood Ratio), FPE (Final Prediction Error), SIC ve HQ (Hannan Quinn) kriterlerinden yararlanılarak uygun gecikme uzunluğu 1 olarak belirlenmiştir.

Tablo: 3

VAR Modeli Gecikme Uzunluğu Analizi

\begin{tabular}{|cccccc|}
\hline Gecikme & LR & FPE & AIC & SIC & HQ \\
\hline $\mathbf{0}$ & NA & 22321.54 & 27.04048 & 27.30711 & 27.13252 \\
$\mathbf{1}$ & $327.2958^{*}$ & $1.512874^{*}$ & 17.40848 & $19.27490^{*}$ & $18.05277^{*}$ \\
$\mathbf{2}$ & 48.16936 & 1.604248 & 17.27611 & 20.74231 & 18.47264 \\
$\mathbf{3}$ & 33.22701 & 2.754918 & $17.25656^{*}$ & 22.32255 & 19.00534 \\
\hline
\end{tabular}

Tablo: 4

Johansen ve Juselius Eşbütünleşme Testi Sonuçları

\begin{tabular}{|c|c|c|c|c|c|c|c|}
\hline \multirow[t]{2}{*}{ Değișkenler } & \multirow[b]{2}{*}{ Hipotezler } & \multicolumn{3}{|c|}{ Maksimum Özdeğer İstatistiği } & \multicolumn{3}{|c|}{ İz İstatistiği } \\
\hline & & İstatistik & $\begin{array}{c}\text { Kritik Değer } \\
(\% 5)\end{array}$ & Anlamlılık & İstatistik & $\begin{array}{c}\text { Kritik Değer } \\
(\% 5)\end{array}$ & Anlamlılık \\
\hline LY & $\mathrm{H}_{0}: \mathrm{r}=0^{\mathrm{b}}$ & 132.7968 & 95.75366 & 0.0000 & 42.75162 & 40.07757 & 0.0244 \\
\hline PF & $\mathrm{H}_{0}: \mathrm{r} \leq 1^{\mathrm{b}}$ & 90.04521 & 69.81889 & 0.0005 & 41.80842 & 33.87687 & 0.0046 \\
\hline YAT & $\mathrm{H}_{0}: \mathrm{r} \leq 2^{\mathrm{b}}$ & 48.23679 & 47.85613 & 0.0460 & 31.85469 & 27.58434 & 0.0133 \\
\hline GFCE & $\mathrm{H}_{0}: \mathrm{r} \leq 3$ & 16.38210 & 29.79707 & 0.6851 & 10.85056 & 21.13162 & 0.6622 \\
\hline TİC & $\mathrm{H}_{0}: \mathrm{r} \leq 4$ & 5.531535 & 15.49471 & 0.7501 & 4.914704 & 14.26460 & 0.7526 \\
\hline INF & $\mathrm{H}_{0}: \mathrm{r} \leq 5$ & 0.616831 & 3.841466 & 0.4322 & 0.616831 & 3.841466 & 0.4322 \\
\hline
\end{tabular}

Not: $b$, ilgili katsayının \%5 düzeyinde anlamlı olduğunu göstermektedir.

VAR modeli ile belirlenen gecikme uzunluğu doğrultusunda uygulanan Johansen ve Juselius eşbütünleşme testinin sonuçları Tablo: 4'de yer almaktadır. Bu sonuçlara göre; maksimum özdeğer istatistiği ve iz istatistiği değeri \% 5 anlamlılık düzeyindeki kritik değerlerden daha büyük olduğu için, $\mathrm{H}_{0}: \mathrm{r}=0$ seriler arasında eşbütünleşme ilişkisi yoktur hipotezi reddedilmiştir. Bu sonuca göre, seriler arasında en az bir tane eşbütünleşik vektör olduğunu söylemek mümkündür. Diğer yandan hem maksimum özdeğer hem de iz testi 
sonuçlarına göre, seriler arasında en çok $2\left(\mathrm{H}_{0}: \mathrm{r} \leq 2\right)$ eşbütünleşik vektör olduğu yönündeki hipotez $\% 5$ anlamlılık düzeyinde reddedilememiş̧ir. Buna göre, seriler arasında en çok 2 tane eşbütünleşik vektör söz konusudur. Bu sonuç ele alınan seriler arasında eşbütünleşme ilişkisinin olduğunu yani serilerin uzun dönemde birlikte hareket ettiğini göstermektedir.

Eşbütünleşme analizi sonucu elde edilen normalize edilmiş denklem ise (2) nolu denklemde yer almaktadır. Parantez içindeki değerler standart hataları göstermek üzere denklemde yer alan katsayılar anlamlı ve işaretleri teorik beklentiyle uyumlu çıkmıştır. Denkleme göre, politik özgürlükler endeksinin değerindeki bir yükselme iktisadi büyümeyi olumsuz etkilemektedir. Politik özgürlükler endeks değerinin yükselmesi (7'ye yaklaşması) ülkenin politik özgürlükler bakımından daha kötü duruma gelmesi anlamına geldiğinden elde edilen bu bulgu politik özgürlükler düzeyindeki bir iyileşmenin iktisadi büyümeyi arttırdığını göstermektedir. Çalışmada elde edilen bu sonuç; Leschke (2000), Ulubaşoğlu ve Doucouliagos (2004) ve Yıldırım (2010)'ın bulgusuyla örtüşmektedir. Diğer yandan denkleme göre; yatırımlar, kamu tüketim harcamalarının GSYH'daki payı ve ticaretin GSYH'daki payı ile iktisadi büyüme arasında pozitif, enflasyon oranı ile iktisadi büyüme arasında ise negatif yönlü bir ilişki söz konusudur.

$$
\begin{aligned}
\mathrm{LY}= & -0.0653 \mathrm{PF}+0.0098 \mathrm{YAT}+0.0184 \mathrm{GFCE}+0.0320 \mathrm{TIC}-0.0021 \mathrm{INF} \\
& (0.03678)(0.00610) \quad(0.00889) \quad(0.00161)
\end{aligned}
$$

\subsection{Hata Düzeltme Modeli}

Granger (1988), seriler arasında eşbütünleşme ilişkisinin varlığı durumunda, seriler arasındaki kısa dönemli nedensellik ilişkisinin hata düzeltme modeli çerçevesinde belirlenmesinin daha uygun olacağını belirtmiş̧ir. Hata düzeltme modeli, seriler arasındaki uzun dönem dengesi ile kısa dönem dinamikleri arasında ayrım yapmak ve kısa dönem dinamiklerinin belirlenmesinde kullanılan bir yöntemdir. Bu doğrultuda, çalışmada seriler arasındaki uzun dönemli ilişki belirlendikten sonra, seriler arasındaki nedensellik ilişkisinin belirlenmesinde hata düzeltme modeli kullanılmıştır. Hata düzeltme modeli test sonuçları Tablo: 5'de sunulmuştur.

Tablo: 5'de yer alan hata düzeltme modeli sonuçlarına göre, hata düzeltme teriminin $\left(\mathrm{EC}_{\mathrm{t}-1}\right)$ işareti beklenildiği gibi negatif ve istatistiksel olarak anlamlı çıkmıştır. $\mathrm{Bu}$ durum seriler arasında bir yakınsamayı işaret etmektedir. Ancak kısa dönem ilişkileri gösteren değişkenlerin katsayıları ticaret ve enflasyon oranı değişkenleri dışında anlamlı çıkmamıştır. Bu sonuç, kısa dönemde seriler arasında ilişki olmadığını göstermektedir.

Çalışmada ayrıca modelin güvenilirliğini kontrol etmek amacıyla otokorelasyon, değişen varyans ve normallik testleri yapılmış ve bu testlerden elde edilen istatistikler, Tablo: 5'de yer alan hata düzeltme modeline ilişkin diagnostik istatistiklerde sunulmuştur. Buna göre, modelde otokorelasyon sorununun olup olmadığı belirlemek amacıyla yapılan 
otokorelasyon testi sonucunda elde edilen LM istatistiğine göre modelde otokorelasyon sorunu yoktur. Ayrıca yapılan değişen varyans testi sonucunda elde edilen ki-kare değeri de hata düzeltme modelinde değişen varyans sorununun olmadığg göstermektedir. Son olarak yapılan normallik testinden elde edilen Jarque-Bera istatistiğine göre, hata düzeltme modelinin hata terimlerinin normal dağılıma sahip olduğu tespit edilmiştir.

Tablo: 5

\section{Hata Düzeltme Modeli Test Sonuçları}

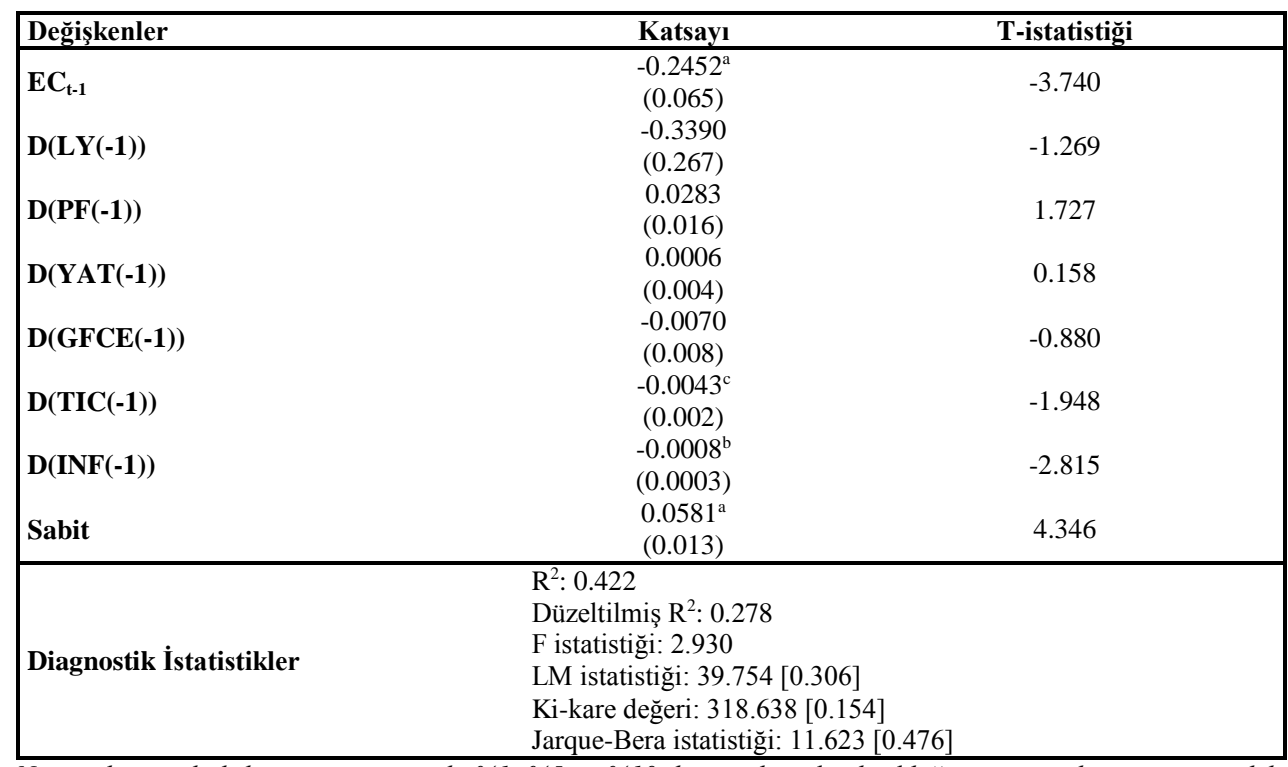

Not: $a, b$ ve c ilgili katsayının strast ile \%1, \%5 ve \%10 düzeyinde anlaml olduğunu; normal parantez içindeki değerler standart hatayl, köşeli parantez içindeki değerler ise anlamlılık düzeyini göstermektedir.

Grafik: 1'de ise sistemin AR karakteristik polinom kökleri sunulmuştur. Grafiğe göre, AR köklerinin tümünün birim çemberin içinde yer alması modelin güvenirliliğini göstermektedir. Sonuç olarak, hem diagnostik testler hem de AR köklerinin yapısı eşbütünleşme analizini desteklemektedir. 


\section{Grafik: 1}

\section{AR Karakteristik Polinom Kökleri}

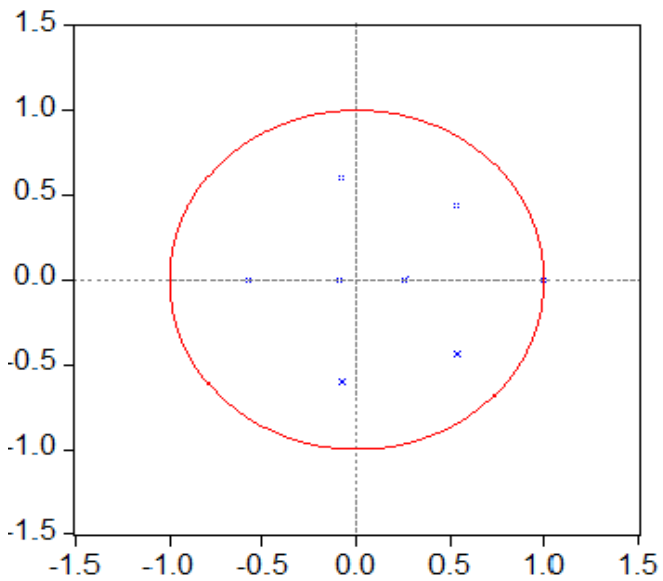

\section{Sonuç ve Değerlendirme}

Bu çalışmada kurumsal yapı ve iktisadi büyüme ilişkisi Türkiye örneği için test edilmiştir. Bu doğrultuda, kurumsal yap1 ve iktisadi büyüme arasındaki uzun dönemli ilişkinin varlığı Johansen ve Juselius eşbütünleşme yöntemi kullanılarak araştırılmış ve ele alınan değişkenler arasında uzun dönemde bir ilişki olduğu sonucuna varılmıştır. Bu sonuç, kurumsal yapının bir unsuru olarak, politik özgürlüklerin iktisadi büyümedeki artışın önemli bir nedeni olduğunu savunan çalışmaların (Leschke, 2000; Ulubaşoğlu ve Doucouliagos, 2004; Yıldırım, 2010) bulguları ile örtüşmektedir. Değişkenler arasındaki eşbütünleşme ilişkisinin varlığına bağlı olarak daha sonra hata düzeltme modeli kurularak söz konusu değişkenler arasındaki kısa ve uzun dönemli ilişki araştırılmış ve kısa dönemde kurumsal yap1 ve iktisadi büyüme arasında bir ilişki tespit edilememiş̧ir. Elde edilen bu bulgu, Siddiqui ve Ahmed (2010)'in kurumların büyüme üzerindeki olumlu etkisinin kısa vadeli değil özellikle uzun vadeli büyüme için daha şiddetli olarak ortaya çıktığı yünündeki görüşünü destekler niteliktedir. Bu doğrultuda kurumsal yapının gelişmesi yüzyıllar sürecek bir olgu olduğundan, kurumsal yapının büyüme üzerindeki etkisinin kısa vadede anlamsız olduğu yönündeki bulgunun literatürle uyumlu olduğunu söylemek mümkündür.

Türkiye'de kurumsal yapının uzun dönemde büyümeyi etkileyen bir faktör olması Türkiye'de kurumsal yapının gelişmesi adına alınacak önlemlerin büyüme sürecindeki önemini ortaya koymaktadır. Bu sonuçtan yola çıkarak Türkiye'de temel hak ve özgürlükler, mülkiyet hakları, yolsuzluk vb. kurumsal alanlarda iyileştirmeler yaparak daha sağlam bir kurumsal yapıya sahip olunması neticesinde uzun dönemde daha yüksek bir ekonomik 
performansa erişilebileceğini söylemek mümkündür. Yeni anayasa çalışmalarının da bu sürece katkı sağlayacağı düşünülmektedir.

Türkiye'deki kurumsal yapının güçlendirilmesi adına alınması gereken önlemlerin başında temel hak ve özgürlüklere daha fazla serbestlik tanınması gelmektedir. Bu kapsamda Türkiye'nin kurumsal yapısına ilişkin çeşitli raporlarda ${ }^{4}$ yer alan Türkiye hakkındaki değerlendirmelerde temel haklara ilişkin olarak; düşünce, din ve vicdan özgürlüğü konusunda bazı ilerlemeler kaydedilmiş olmakla beraber özellikle ifade özgürlüğü ve basın özgürlüğü konusunda ciddi adımların atılması gerektiğinin altı çizilmektedir. Bu durum söz konusu alanlarda köklü reformlar yapılması gerektiğinin bir göstergesi olarak ifade edilebilir. Bunun yanında mülkiyet hakları kapsamında özellikle fikri mülkiyet haklarının korunması konusunda yasal önlemler alınmalıdır. Mülkiyet haklarının korunması bir ülkedeki teknoloji, verimlilik ve yatırımlar ile doğrudan ilişkili olduğundan ekonominin işleyişine etki etmektedir. $\mathrm{Bu}$ doğrultuda mülkiyet haklarının daha iyi korunması ekonomik gelişmeye katkı sağlayabilir.

Türkiye'de temel hak ve özgürlükleri güçlendirmenin bir yolu da anayasa reformu aracılığıyla olabilir. $\mathrm{Bu}$ amaçla yeni anayasanın oluşturulması sürecince yargının bağımsızlığı ve tarafsızlığı konusunda da $\mathrm{AB}$ standartları doğrultusunda hukuki ve kurumsal düzenlemeler yapılmalıdır. Bu şekilde insan hak ve özgürlüklerinin güvence altına alınmış olduğu demokratik bir toplum olmanın gereklerini yerine getirmede önemli bir adım atılmış olacaktır. Bu kapsamda demokrasi düzeyi; politik istikrarsızlık, beşeri sermaye, gelir eşitsizliği ve mülkiyet hakları gibi çeşitli kanallarla büyüme üzerinde etkili olduğundan demokrasi düzeyinin gelişmesiyle beraber ülkelerin iktisadi performansının bundan olumlu etkileneceği ifade edilebilir.

Türkiye'nin kurumsal yapısına ilişkin raporlardaki bir diğer değerlendirme yolsuzlukla mücadele konusunda son yıllarda sınırlı bir ilerleme kaydedildiği yönündedir. Kurumsal yapının önemli bir göstergesi olan yolsuzluk düzeyinin yüksek olması, Türkiye'nin demokratik kurumların güveninin sarsılmasına yol açmakta, kurumların tarafsızlı̆̆ı, gücü, şeffaf ve hesap verebilir olmasına engel teşkil etmektedir. Dolayısıyla yolsuzlukla mücadelede daha fazla ilerleme sağlanması kamu kurumlarının daha şeffaf, açık ve hesap verebilir olarak algılanmasını beraberinde getirecektir. Bu doğrultuda yolsuzluğun azaltılması için belirlenen strateji, plan ve programların etkin bir şekilde uygulanması Türkiye'nin ekonomik performansını olumlu etkileyebilecektir.

4 Ayrıntıl bilgi için bakinı: Avrupa Komisyonu (COM) 2012 Türkiye Illerleme Raporu ve Freedom House Basın Özgürlüğ̈̈ 2012 (Freedom of the Press 2012) Raporu. 


\section{Kaynakça}

Acemoğlu, Daron vd. (2001), "The Colonial Origins of Comparative Development: An Empirical Investigation”, American Economic Review, 1369-1401.

Acemoğlu, Daron vd. (2003), "Institutional Causes, Macroeconomic Symptoms Volatility, Crises and Growth", Journal of Monetary Economics, 50, 49-123.

Akçay, Selçuk (2002), "Corruption and Economic Growth: Across-National Study”, Ankara Üniversitesi SBF Dergisi, 57(1), 1-13.

Arslan, Ünal (2011), "Siyasi İstikrarsızlık ve Ekonomik Performans: Türkiye Örneği”, Ege Academic Review, 11(1), 73 -80.

Asteriou, Dimitrios \& Simon Price (2000), "Political Instability and Economic Growth: UK Time Series Evidence", Scottish Journal of Political Economy, 48(4), 383-399.

Barro, Robert J. (1994), “Democracy and Growth”, NBER Working Paper, 4909, <http://www.nber.org/papers/w4909.pdf?new_window=1>, 05.06.2011.

Beşkaya, Ahmet \& Ömer Manan (2009), "Ekonomik Özgürlükler ve Demokrasi ile Ekonomik Performans Arasındaki İlişkinin Zaman Serileri ile Analizi: Türkiye Örneği”, Zonguldak Karaelmas Üniversitesi Sosyal Bilimler Dergisi, 5(10), 47-76.

Carlsson, Fredrik \& Susana Lundström (2001), "Economic Freedom and Growth: Decomposing the Effects", Göteborg University, Working Paper in Economics, No. 33.

COM (2011), "Türkiye 2011 Y1lı İlerleme Raporu”, Avrupa Komisyonu, Brüksel, <http://www.abgs.gov.tr/files/AB_Iliskileri/AdaylikSureci/IlerlemeRaporlari/2011_ilerle me_raporu_tr.pdf $>, 15.01 .2012$.

Commons, John R. (1931), "Institutional Economics”, American Economic Review, 21(4).

Dawson, John W. (2003), “Causality in the Freedom-Growth Relationship”, European Journal of Political Economy, 19, 479-495.

Dawson, John W. (2010), "Macroeconomic Volatility and Economic Freedom-a Preliminary Analysis", Economic Freedom of the World: 2010, Annual Report, 175-185.

De Haan, Jakob \& Clemens L.J. Siermann (1995), "New Evidence on the Relationship between Democracy and Economic Growth", Public Choice, 86, 175-198.

Dünya Bankası (2011), WDI Veri Tabanı.

Freedom House (2012), Freedom of the Press 2012, <http://www.freedomhouse.org/report/freedompress/freedom-press-2012>, 10.01.2013.

Gwartney, James vd. (2004), "Economic Freedom, Institutional Quality, and Cross-Country Differences in Income and Growth", Cato Journal, 24(3), 205-233.

Gwartney, James vd. (2010), "Economic Freedom of the World”, 2010 Annual Report.

Hamilton, Walton (1932), Institutions, Edwin R. Seligman and Alvin Johnson (der.), Encyclopaedia of Social Sciences, içinde (84-89), London: Routledge.

Hanke, Steve H. \& Stephen J.K. Walters (1997) "Economic Freedom, Prosperity, and Equality: A Survey”, Cato Journals, 17(2), 117-146.

Kasper, Wolfang (2007), Ekonomik Özgürlük ve Gelişme, Mülkiyet Haklarl, Rekabet ve Refah Üzerine Bir İnceleme, (Çev. Bahadır Akın), Ankara: Liberte Yayınları. 
Kasper, Wolfgang \& Manfred E. Streit (1998), Institutional Economics, Social Order and Public Policy, Northampton, Massachusetts: Edward Elgar Publishing.

Leschke, Martin (2000), "Constitutional Choice and Prosperity: A Factor Analysis", Constitutional Political Economy, 11, 265-279.

List, Friedrich (1916), The National System of Political Economy, Translated by George -Auguste Matile, Henri Richelot, Philadelphia: J.B. Lippincott \& Co.

Mauro, Paolo (1995), “Corruption and Growth”, The Quarterly Journal of Economics, 110, 681-713.

Mitchell, Wesley Clair (1950), Backward Art of Spending Money and Other Essays, Reprints of Economic Classics, New York: A.M. Kelley.

North, Douglass C. (1991), "Institutions", The Journal of Economic Perspectives, 5 (1), 97-112.

Puddington, Arch (2011), Freedom in the World 2011: The Authoritarian Challenge to Democracy, Freedom House.

Rodrik, Dani (2000), "Institutions for High Quality Growth: What they are and How to Acquire them", National Bureau of Economic Research Working Paper, 7540.

Rutherford, Malcolm (2000), "Institutionalism between Wars”, Journal of Economic Issues, 34 (2), 291-303.

Rutherford, Malcolm (2009), “Towards a History of American Institutional Economics”, Journal of Economic Issues, XLIII (2), 309-318.

Sabatini, Fabio (2006), "Social Capital, Public Spending and the Quality of Economic Development: The Case of Italy", Feem Working Paper, 14.06.

Şanlısoy, Selim \& Recep Kök (2010), "Politik İstikrarsılık - Ekonomik Büyüme İlişkisi: Türkiye Örneği (1987-2006)”, Dokuz Eylül Üniversitesi İIBF Dergisi, 25 (1), 101-125.

Scully, W. Gerald (2002), "Economic Freedom, Government Policy and the Trade-Off between Equity and Economic Growth", Public Choice, 113, 77-96.

Siddiqui, Danish Ahmed \& Qazi Masood Ahmed (2010), "Institutions and Economic Growth: A Cross Country Evidence", Mpra Paper, No. 19747.

Tanzi, Vito \& Hamid Davodi (1997), “Corruption, Public Investment and Growth”, IMF Working Paper.

Tavares, J. \& R. Wacziarg (2001), “How Democracy Affects Growth”, European Economic Review, 45, 1341-1378.

Torstensson, Johan (1994), "Property Rights and Economic Growth: An Empirical Study" Kyklos, 47, 231-247.

Ulubaşoğlu, Mehmet A. \& Chris Doucouliagos (2004), "Institutions and Economic Growth: A Systems Approach", Econometric Society 2004, Australasian Meetings Paper, No. 63.

Vanssay, Zane A. \& Xavier De Spindler (1994), “Freedom and Growth: Do Constitutions Matter?", Independent Institute Working Paper, Number 24.

Veblen, Thorstein (1919), The Place of Science in Modern Civilization and Other Essay, New York, Huebsch.

Yıldırım, Selim (2010), “Kurumların Dinamik Yapısının Ekonomik Büyüme Üzerine Etkisinin Analizi”, Anadolu Üniversitesi Sosyal Bilimler Dergisi, 10(3), 111-126. 
Ek: 1

Kurumların İktisadi Büyüme Üzerindeki Etkilerini İnceleyen Çalışmalar

\begin{tabular}{|c|c|c|c|c|}
\hline $\begin{array}{l}\text { Çalışmanın } \\
\text { Yazarı }\end{array}$ & $\begin{array}{l}\text { Kapsadığı } \\
\text { Dönem }\end{array}$ & Ele Alınan Ülkeler & Kullanılan Kurumsal Ölçüm & Çalışmanın Sonucu \\
\hline $\begin{array}{l}\text { Acemoğlu ve } \\
\text { diğerleri } \\
(2003)\end{array}$ & 1970-1997 & 96 ülke & Kurumsal kalite & Büyüme üzerinde pozitif etki \\
\hline Akçay (2002) & $1960-1995$ & 54 ülke & Yolsuzluk & $\begin{array}{l}\text { Yolsuzluk ile iktisadi büyüme } \\
\text { arasında negatif ilişki }\end{array}$ \\
\hline Arslan (2011) & $1987-2007$ & Türkiye & Politik istikrarsızlık & $\begin{array}{l}\text { GSYH'dan politik istikrarsızlığa } \\
\text { doğru tek yönlü nedensellik ilişkisi }\end{array}$ \\
\hline $\begin{array}{l}\text { Asteriou ve } \\
\text { Price, }(2000)\end{array}$ & 1961-1997 & İngiltere & $\begin{array}{l}\text { Siyasi istikrarsızlık (terör, } \\
\text { darbe, seçim vs.) }\end{array}$ & Büyüme üzerinde negatif etki \\
\hline Barro (1994) & $1960-1990$ & 100 ülke & Demokrasi & $\begin{array}{l}\text { Demokrasinin iktisadi büyüme } \\
\text { üzerindeki etkisi belirsiz }\end{array}$ \\
\hline $\begin{array}{l}\text { Beşkaya ve } \\
\text { Manan (2009) }\end{array}$ & $1970-2005$ & Türkiye & $\begin{array}{l}\text { Demokrasi ve ekonomik } \\
\text { özgürlük }\end{array}$ & $\begin{array}{l}\text { Demokrasinin iktisadi büyüme } \\
\text { üzerindeki etkisi belirsiz, ekonomik } \\
\text { özgürlükler büyüme üzerinde pozitif } \\
\text { etki }\end{array}$ \\
\hline $\begin{array}{l}\text { Carlsson ve } \\
\text { Lundström } \\
(2001)\end{array}$ & $1975-1995$ & 74 ülke & Ekonomik özgürlük & $\begin{array}{l}\text { Ekonomik özgülüğün bazı bileşenleri } \\
\text { büyüme üzerinde pozitif etkiliyken } \\
\text { bazı bileşenleri negatif etkilidir. }\end{array}$ \\
\hline Dawson (2003) & $1970-2000$ & $\begin{array}{l}\text { Verisi olan tüm } \\
\text { ülkeler }\end{array}$ & Ekonomik özgürlük & İktisadi büyüme üzerinde pozitif etki \\
\hline Dawson (2010) & $1980-2007$ & 85 ülke & Ekonomik özgürlük & $\begin{array}{l}\text { Ekonomik özgürlük ile } \\
\text { makroekonomik oynaklık arasında } \\
\text { negatif ilişki }\end{array}$ \\
\hline $\begin{array}{l}\text { De Haan ve } \\
\text { Siermann } \\
\text { (1995) }\end{array}$ & $\begin{array}{l}1973-1988 \\
1961-1992\end{array}$ & 96 ülke & Demokrasi & $\begin{array}{l}\text { Büyüme ile arasında güçlü bir ilişsi } \\
\text { yok }\end{array}$ \\
\hline Mauro (1995) & $1980-1983$ & 67 ülke & Yolsuzluk & Büyüme üzerinde negatif etki \\
\hline Rodrik (2000) & $1970-1989$ & 90 ülke & Demokrasi & İktisadi büyüme üzerinde pozitif etki \\
\hline Sabatini (2006) & $1998-2002$ & İtalya & $\begin{array}{l}\text { Sosyal sermaye (güçlü aile } \\
\text { bağları, zayıf gayri resmi bağlar, } \\
\text { gönüllü organizasyonlar, siyasi } \\
\text { katılım) }\end{array}$ & $\begin{array}{l}\text { Sosyal sermayenin farklı boyutları, } \\
\text { çeşitli ekonomik sonuçlar üzerinde } \\
\text { farklı etkiler gösterir }\end{array}$ \\
\hline $\begin{array}{l}\text { Siddiqui ve } \\
\text { Ahmed (2010) }\end{array}$ & & 43 ülke & Kurumsal kalite & $\begin{array}{l}\begin{array}{l}\text { Büyüme üzerinde anlamlı ve pozitif } \\
\text { etki }\end{array} \\
\end{array}$ \\
\hline $\begin{array}{l}\text { Şanlısoy ve } \\
\text { Kök (2010) }\end{array}$ & $1987-2006$ & Türkiye & Politik istikrarsızlık & İktisadi büyüme üzerinde negatif etki \\
\hline Scully (2002) & 1975- 1990 & $\begin{array}{l}\text { Birçok gelişmiş ülke } \\
\text { ve bazı yeni } \\
\text { sanayileşen Asya } \\
\text { ülkeleri }\end{array}$ & Ekonomik özgürlük & İktisadi büyüme üzerinde pozitif etki \\
\hline $\begin{array}{l}\text { Tanzi ve } \\
\text { Davodi (1997) }\end{array}$ & $1980-1995$ & OECD ülkeleri & Yolsuzluk & $\begin{array}{l}\text { Büyüme üzerinde negatif etki (yatırım } \\
\text { kanalıyla) }\end{array}$ \\
\hline $\begin{array}{l}\text { Tavares ve } \\
\text { Wacziarg } \\
(2001)\end{array}$ & 1970-1989 & $\begin{array}{l}65 \text { sanayi ülkesi ve } \\
\text { gelişmekte olan ülke } \\
\text { grubu }\end{array}$ & Demokrasi & $\begin{array}{l}\text { İktisadi büyüme üzerindeki genel } \\
\text { etkisi negatif ve orta düzeyde }\end{array}$ \\
\hline $\begin{array}{l}\text { Torstensson } \\
\text { (1994) }\end{array}$ & 1976-1985 & 68 ülke & Mülkiyet hakları & $\begin{array}{l}\text { Devlet mülkiyeti ve büyüme arasında } \\
\text { negatif ve anlamlı olmayan ilişki; keyfi } \\
\text { el koyma ile büyüme arasında negatif } \\
\text { ve anlamlı ilişki }\end{array}$ \\
\hline $\begin{array}{l}\text { Vanssay ve } \\
\text { Spindler } \\
(1994)\end{array}$ & $1985-1988$ & 100 ülke & Ekonomik özgürlük & Büyüme üzerinde etkisiz \\
\hline
\end{tabular}


Seyfettin ARTAN \& Pınar HAYALOĞLU 